\title{
A Narrative Inquiry into the Leadership Practice in a South African School through a Servant-Leadership Lens
}

\author{
G. M. Steyn \\ Department of Further Teacher Education, College of Education, University of South Africa, \\ PO Box 392, Pretoria 0003 South Africa \\ Telephone : +27 12664 4256, Mobile: +2782 886 7468, E-mail: steyngm1@unisa.ac.za
}

KEYWORDS School Leadership. Laub's Model of Servant-leadership. Principalship

\begin{abstract}
Apart from international narrative studies on school principals the use of a narrative has only been applied in a limited manner to studies focusing on school principals in South Africa. The purpose of this article was therefore to explore the way in which the principal in the study exhibited the aspects of the servant- leadership model through a narrative analysis. The narrative of a South African principal was interpreted in the light of the six characteristics of Laub's servant-leadership organisational model. The following categories emerged from the data analysis: Valuing people: "I have been extra blessed with a great love for people"; Developing people: Focus on the 'strong points' and not the "weak points'; Building community: Start trusting and using people... it's a general principle"; Displaying authenticity: "Compassion ... it's a very small thing, perhaps even insignificant"; Providing leadership: "We are missing something about the child"; and Sharing leadership: "The secret of any business ... is ownership." This study shows the intricate relationship between the contextual factors in a particular school and the execution of school leadership, in particular servant-leadership.
\end{abstract}

\section{INTRODUCTION}

Worldwide social and economic changes are modifying the context of leadership in schools (Day and Leithwood 2007: vii). This explains the global increase in the interest in studying school leadership during the last two decades (Gurr et al. 2006: 372; Slater et al.2008: 702). These studies show extensive evidence regarding the importance of school leadership in creating effective schools (Macneil et al. 2009: 76; Krüger et al. 2007: 1; Drysdale et al. 2009: 697).

Research also indicates that leadership, which includes school leadership, is viewed as one of the most complex of social processes (Fry and Krieger 2009: 1667; Leithwood and Day 2007: 1). This complexity may explain the existence of the many leadership theories (Werner 2003: 186), such as trait theories (Barker 2001; Robbins and Decenzo 2007), transformational leadership (Robbins and Decenzo 2007; Nel et al. 2008), situational leadership (Hersey et al. 2008) and servant leadership (Trompenaars and Voerman 2010; Tidball 2012).

Leadership is considered to be the ability of leaders to demonstrate how they influence others to act in a certain way (Robbins and Decenzo 2007: 247; Nel et al. 2008: 356; Hersey et al. 2008: 6; Werner 2003: 186). A school principal is regarded as the key educational leader and the one particular person in a school who is in the best position to exercise school leadership (Gurr et al. 2006: 371). By means of his or her direction, encouragement, support, sensitivity and consideration, a principal encourages and influences followers to achieve the set goals (cf. Robbins and Decenzo 2007: 247; Nel et al. 2008: 356).

As in the case of Johnson's study (2009), this study is yet another response to the study done by Møller and Eggen (2005: 335) to view leadership "practice" as a narrative which "may open up approaches to analysis which would be useful in exploring the complexities of leadership practice in schools". Apart from international narrative studies on school principals (Brumley 2007; Cooper and Heck 1995; Greer 2009; Johnson 2009; Slater 2011), the use of a narrative, which has informed this study, has only been applied in a limited manner to studies focusing on school principals in South Africa. South African principals' narratives include the study on educational changes in a sample of the best Eastern Cape schools (Lawrence 2007), grounded narratives of school principals during a decade of changes (Mphahlele 2009); describing the use of metaphors in respect of school leadership among three women school principals (Phendla 2004), and constructing the self as a leader who contributes to an effective African-centred leadership style (Mogadime et al. 
2010). However, none of the studies provide a narrative on how a leadership practice compares to the servant-leadership model. The purpose of this article is therefore to determine how the narrative of a South African principal can be interpreted in the light of the six characteristics of Laub's servant-leadership organisational model.

\section{Objective of the Study}

Building on the work of Spillane'study (2005) that focuses on all the interactions of school leaders, their followers and the school context and Schall et al.'s study (2004:1) that provides an an appreciative focus on the 'work of leadership', the researcher examined the life story of the leadership practice of a South African principal as it relates to servant leadership. The study therefore attempted to determine how the leadership of a South African principal can be interpreted in the light of Laub's servant-leadership model that focuses on the following aspects: (a) valuing people, (b) developing people, (c) building community, (d) displaying authenticity, (e) providing leadership, and (f) sharing leadership.

\section{Conceptual Framework}

Although considerable conceptual progress has been made on school leadership, more research is required to address the question of the paths through which a school principal achieves school effectiveness (Krüger et al. 2007: 1). The researcher joined other leadership theorists who believe that leadership is a socially constructed phenomenon (Ladkin 2010: 21; Schall et al. 2004: 2 ) which is constructed over time as individuals interact with each other. Having a constructionist approach to leadership, one finds it possible to reveal the relational and sense-making aspects of a principal's leadership work (Schall et al. 2004: 3 ). Moreover, the narrative which is used in this study is socially constructed through a number of interviews and interactions between the participant and the researcher (Hollingsworth and Dybdahl 2007: 151).

The other lens that is used in this study is that of servant leadership. The servant-leadership model resembles that of transformational leadership, but differs in the sense that servant leaders see themselves as servants first, and leaders second (Greenleaf 1998: 15; Van Tassell 2006:
15). Robert Greenleaf, who questioned traditional, authoritarian leadership styles, created the concept "servant leadership" (Greenleaf 1998: 15). Servant leadership is a holistic approach to leadership and requires a rethinking of the hierarchy between leaders and employees (Spears 2004: 7-8). To Greenleaf (1998: 18), "the servant-leader is servant first" (Greenleaf 1998: 18). In line with the above mentioned view, Laub (2004: 3) defines servant leadership as "an understanding and practice of leadership that places the good of those led over the self-interest of the leader" (Laub 2004: 23). Servant leadership is strongly based in both caring and ethical behaviour, emphasises increased service to others, promotes the valuing and growth of people, and shares power in decision making (Greenleaf 1998: 19; Spears 2004: 7-8; Ross 2006: 64; Tidball 2012: 36; Van Tassell 2006: 16).

Although Laub's servant-leadership model is not the only servant-leadership model available (Wong and Page 2003; Van Tassell 2006; Patterson 2003), it provides "a clear framework for the underlying meaning and characteristics of servant-leadership" (Brumley 2007: 29) and is regarded as a standard for a servant-leadership model (Ross 2006; Van Tassell 2006). Brumley's study (2007: 30) in particular shows that Laub's instrument successfully determined the degree to which an organisation is servant led (Ross 2006: 105; Van Tassell 2006: 63). Laub's Organizational Leadership Assessment model (OLA) (1999: 23) reveals the following characteristics of servant leadership: (a) valuing people, (b) developing people, (c) building community, (d) displaying authenticity, (e) providing leadership, and (f) sharing leadership. This study explored "servant leadership as a practice of an individual principal" (Hagstrom 2004: 89) and, in particular, examined the way in which the principal exhibited the aspects of the servant leadership model through a narrative analysis.

\section{RESEARCH DESIGN}

The researcher became acquainted with the primary school in the study via a shadowing exercise of the principal when he was carefully observed for a few months in 1992. The school and principal had also participated in a number of other studies which did not particularly focus on the leadership practice of the principal, but provided valuable insights into his leadership 
practice (Steyn 1994,2006, 2007, 2009, 2010). During his years of principalship which was revealed in the mentioned studies, this school displayed the following characteristics: purposive and flexible leadership; teachers' and students' commitment to work; a safe and organisationally functioning school context (cf. Danielson 2007: 18; Jacobson et al. 2005: 614); a culture of care and concern in the school (cf. Jacobson et al. 2005: 613; Saðnak 2010: 1145); and a functioning relationship with the parents and community. Apart from new empirical data in this study, the school's DVD and data from previous studies in the school - as mentioned earlier - were included.

The primary school in the study performed exceptionally well in various aspects of the school. The school's achievements included the following (Steyn 2012): They previously won garden competitions in Pretoria; the curriculum was supplemented by subjects students needed, such as Study methods, Remedial teaching and English as a spoken language; the school employed an extensive system to reward staff, students, parents and 'friends of the school'; and the school had least 20 different parent committees.

In this study the researcher used the methodology of narrative inquiry (Bell 2002: 207; Creswell 2007: 93; Denzin and Lincoln 2008: 65; Greer 2009: 269; Oplatka 2004: 57; Riesmann 2011: 203; Slater et al. 2008: 705), particularly that of a narrative analysis (Given 2008: 539) to inquire into a principal's stories of his leadership practice. Such an inquiry presents experiences of a participant holistically "in all its complexity and richness" (Bell 2002: 209) and encompassed "extended accounts" that developed over multiple contacts (Given 2008: 539) with the principal.

The principal's story was revealed through an open-ended interview (and follow-up telephone conversations) and field notes in 2010 which exposed the personal perspective of the principal on his leadership practice during his years of principalship. The responses of the principal were considered as 'stories' and the written text in the findings as the 'narrative' (Brumley 2007: 45; Riesmann 2011: 204). To ensure trustworthiness, the data collected were recorded and transcribed and a transcript of the data was sent via e-mail to the participant for member checking to ensure accuracy and reliability (Kelly and Saunders 2010: 128; Muijs et al. 2010: 145). Fur- thermore, the trustworthiness of the study was examined by comparing and contrasting the evidence gleaned from the interview with previous studies within the school (Muijs et al. 2010: 145). Since the data collected were in Afrikaans they were translated into English, considering the idiom in which the stories were told.

As in the case of Johnson's study (2009: 270) the researcher employed an empiricallygrounded narrative to show how a principal portrayed his servant leadership in the telling of his stories. The researcher first approached the text holistically and, by means of re-telling, the researcher reconstructed and integrated sections of the text (Creswell 2007: 158) into the six characteristics of Laub's OLA servant-leadership model. Since Laub's model enabled the researcher to identify critical elements in the principal's story, a thematic form of narrative analysis was used to 'assemble' the events and stories (Given 2008, 540) and build a framework (Riesmann 2011: 206) according to the servantleadership model to reveal the unique features (Creswell 2007: 158) of the principal's servantleadership practice. The researcher coded the participant's narrative from a literary perspective to understand the "storied, structured" form of the data (Saldaòa 2009: 109), which involved "big gulps of text" (Daiute and Lightfoot 2004: 2). In the categorisation of data, both structural (Saldaòa 2009: 68) - in this case Laub's OLA model - and in vivo coding (Creswell 2007: 153) were used to identify the categories. The reason for using in vivo coding was to "prioritize and honour the participant's voice" in the study (Saldaòa 2009: 74), while the conceptual framework of servant leadership provided an appropriate way of structuring the data collected.

\section{FINDINGSOF THE STUDY}

The following categories emerged: Valuing people: "I have been extra blessed with a great love for people"; Developing people: Focus on the 'strong points' and not the 'weak points'; Building community: Start trusting and using people... it's a general principle"; Displaying authenticity: "Compassion ... it's a very small thing, perhaps even insignificant"; Providing leadership: "We are missing something about the child"; and Sharing leadership: "The secret of any business ... is ownership." On another level, the narrative was interpreted by 
means of the servant leadership model to depict the manifestation of the principal's servant-leadership practice.

The school was located in an average to above-average socio-economic environment, although some parents were struggling financially. Throughout his career as principal of the school, he regarded his leadership as a "calling" and that he wanted to make a difference in the lives of others in the school and the community. During his career as principal his leadership style did not change much and he remained focused on the welfare of others. He was inviting and open - a "hands-on" leader as supported by an Australian study (Drysdale et al. 2009: 703).

Valuing People: "I have been extra blessed with a great love for people"

Servant leaders demonstrate valuing people by believing in them, serving people's needs through non-judgmental and receptive listening (Laub 1999: 25). The study revealed that an array of strong personal and professional values and beliefs underpinned the leadership practice of the principal.

It was notably the principal's care, love and respect for people that were paramount in his leadership practice. In the study by Steyn (1994), the principal demonstrated his caring attitude by being visible in classrooms and on the school grounds. In his story he said, "You can't just sit in your office ...you must be among people", and he made an extra effort to learn the name of every child in the school. His love for people was a recurring theme in all his interviews and again confirmed in the 2010 interview: "I think I have been extra blessed with a great love for people - especially for children."

The way in which the principal valued people is disclosed in the following assertion: "My premise - my thing is with people ... I'm very people oriented ... I'm telling you, I love people." They way in which love could be demonstrated was revealed in his explanation: "Doing something unexpected for someone who doesn't expect anything, and who can't give it back ...... It gives me pleasure to do small things for people ...I received the right calling."

The religious beliefs and values of this principal were very strong and obviously had a great influence on his leadership practice (Raihani 2008: 486; Karadað 2009: 1393). When the prin- cipal attended a conference on "Youth with a Mission for Christ" a number of years ago, he was invited to make a prayer request. His request was that the audience should pray that he could love children even more. He believes that, after this event, his sense of love increased.

To illustrate the impact of his love, the principal referred to a "nice" letter from gentleman who had been a learner more or less 20 years ago.

When he was at the school, I walked past him and just touched his head... and that small gesture, made him start observing me ... he said I won't believe what a huge impact I had on his life... It's an insignificant little deed of love and of caring.

His love for children was confirmed by an experienced teacher (Steyn 2006: 6) who mentioned that it was primarily the principal's love for the learners that was so remarkable: "It is the Lord who gives him that love. And I think that is actually the essence ... and I think that is perhaps what you don't get at some of the other schools. They don't have that love." It was not only that his own values that were important to him; he also wished to inculcate important value systems such as love, respect and humility in others. He believed that an appropriate value system could prepare children for a successful place in society.

Apart from valuing people, servant leaders acknowledge the talents that people have and value their development and growth.

\section{Developing People: Focus on the 'strong points' and not the 'weak points'}

Servant leaders develop people by providing opportunities for professional development (PD), modelling appropriate behaviour and building others through affirmation and encouragement (Laub 1999: 25). The principal placed a great emphasis on staff's PD and acknowledged their 'unique' talents. In various studies, the principal referred to the importance of teachers' growth (Steyn 2007, 2009, 2010). In the 2010 interview, he strongly confirmed his belief: "I think the other shortcoming in schools is that we don't develop [people]." The various growth opportunities for staff such as mentoring among colleagues, inducting new staff members, benchmarking with other schools, in-house workshops run by facilitators, showing DVDs 
and sending staff on appropriate workshops sponsored by the school resulted from the principal's focus on staff development. The process of developing people intensified later in the principal's career when he focused on improving people's strengths. With this renewed focus, the number of growth opportunities for role players had also increased.

The principal stated how leaders often wrongly try to develop people by sending them to inappropriate workshops. The principal blamed many schools for not realising that development "has to be an integral part of the whole staff's personal development". He believed that it is necessary to identify a person's talent, his or her "grace" before sending him or her on a workshop:

There are people who are administratively talented ... but you shouldn't allow them to work with people ... Their gift is to work with computers and 'admin'... schools [send people] on courses, but they don't send the right person ... that's why there are so many unhappy people around.

He "quite deeply" believed that it was important to "train them [teachers] in the principles that they are passionate about" (Steyn 2006: 5). In a previous study (Steyn 2006: 5), the principal explained his strategy of assisting teachers in their development. Instead of focusing on the 'weak points' of staff, he identified their 'strong points'. He always searched for appropriate workshops that would benefit both the individual teacher and the school. For development to be effective, the principal believed that he needed to "send them [teachers] on the best courses ... buy the best quality material in the world and ... almost force them [to attend]". Since the school annually budgeted for development programmes, teachers' attendance at such workshops was usually sponsored by the school.

Throughout his career the principal had enriched the school curriculum by, among other things, adding more subjects such as study methods, music and chess and by providing remedial teaching to students at risk. He modelled the importance of human relationships and created various collaborative structures in the school for staff, parents and students to serve on. According to the principal, he was "really the exact opposite of an autocratic leader" and felt he was in the right profession which he considered to be his "calling".
By developing people's potential, it was possible to build a school community that strived towards a common school goal.

\section{Builing Community: "Start trusting and using people ... it's a general principle."}

According to Laub's OLA model (1999: 25), servant leaders build community by building strong personal relationships, by working collaboratively with others, and by valuing the differences of others. To build a community, trust among role players is a prerequisite, as the principal stated: "Start trusting people... it is a general principle" in working as a school community. His trust in people assisted his success in building a harmonious, friendly atmosphere within the school. In reflecting on his leadership success the principal said, "I think the wisdom I got from above to do things at the right time, and the fact that I was able to gather the right people around me, were responsible for my success." The principal believed that "people started doing things for me not because they had to, but because they really wanted to ... hopefully they enjoyed doing it" as a result of developing their potential.

As he went about building a community, the principal had an open door policy: he was present "where things are happening", had numerous formal and informal discussions, sent weekly letters to parents, provided parenting programmes, acknowledged the good work of staff, students and parents, and reached out to the community (the Angel project, a community outreach project, and twinning with a disadvantaged school in Mamelodi). In his own words, he "never spoke of my school; it isn't my school; it has nothing to do with you [me] ... It's our school; it's a joint thing with the children, staff, parents, and even the private sector. I think everyone has an unbelievable say and value."

The principal had not been complacent throughout his years as principal and he had introduced a number of initiatives, such as the $\mathrm{B}+$ initiative to focus on the positive attitudes of people, cultivating winners by introducing various reward systems for learners, teachers, parents and even "friends of the school" and focusing on people by providing an effective client service (Steyn 2009, 2010). Over the years he also modelled the importance of building personal and professional relationships and estab- 
lished collaborative structures in the school in which roles and responsibilities were distributed. Parents had the opportunity to serve on various parent committees, and even join a prayer group, while there were more than 25 committees on which students could serve. By implication, the principal's high regard for being a "family" also revealed his willingness to learn from others and be among the followers he led.

Displaying Authenticity: “Compassion ... it's a very small thing, perhaps even insignificant"

Displaying authenticity is demonstrated by being open and accountable to others, being willing to learn from others and maintaining trust and integrity (Laub 1999: 25). The way in which the principal conveyed authenticity is explained in the following statement.

The thing is it's actually compassion... It's a very small thing, perhaps even insignificant ... like just stopping sometimes and listening to someone. I told the children that perhaps one of the most important things about communication is sometimes just saying nothing. Just keeping quiet and being there for someone who needs you.

Having an open door policy and being available "where things were happening" meant that he was never too busy to listen to the needs and concerns of all the individuals in the school. He regarded himself as humble and believed that humility is "almost the crux of leadership". Although his school was successful in many areas, he believed that he himself had "very few talents" and, given his own talents, the school should have been "an average to below-average school". He referred to Jesus whose "whole ministry was something of humility ... a service to people". Jesus washed people's feet, "the job of a woman or one of the slaves" which was his personal example of being a "servant" to others.

The principal described how he honoured people (his staff members) in "many respects" as his "superiors", which he believed made him "strong". By doing this, "he gave people the freedom to be themselves and to grow and do what they enjoyed. I gave people a lot of freedom". Furthermore, he believed that his unique personality made it easy to do it: "I was fortunate enough to be blessed with a serene personality and calmness."
The principal's experience of challenges during his principalship portrayed his humaneness:

At times I was depressed - being a principal isn't an easy job ... People can be so cruel... it's terrible. But ... if you can't give it [the "pain and the burden"] to the Lord - and say, "Lord, now You take over..." And then things often start to change, because when you carry on fighting, you land in your grave ... What I want to tell you now is my secret. My secret is that I think the Lord, to a great extent, the Lord did the work.

He believed that everybody requires a passion to be successful and his own passion was also commendable. He explained:

I feel that it's passion that makes people succeed in life. Passion can't be extinguished... It has a ripple effect-you need to be able to sell what's inside you ... They [many people] are too busy with the wrong things. They die inside because they don't enjoy what they're doing, and they also make the people around them die because they can't get excited about the things they're involved in.

By displaying authenticity principals show their sincere interest in and understanding of people in the school. In doing this they are also in a better position to direct the behaviour of role players through their leadership support. This type of leadership is directed towards social change by encouraging others through higher levels of values awareness and by ensuring that staff members look beyond their own self-interests for the sake of the group (Norris et al. 2002: 87).

\section{Providing Leadership: "We are missing something about the child"}

Servant leaders provide leadership by envisioning the future, taking the initiative and clarifying goals (Laub 1999: 25). The principal explained the vision and mission of the school on the DVD: "To be the best Afrikaans primary school in the world, where every student, parent and staff member is happy, and every individual student receives the opportunity to develop his/her unique abilities optimally to the honour of God" and "We as dynamic school are committed to excellence, to educate our students with the necessary skills and passion to think creatively, reason critically, communicate effectively and learn continuously in order to become 
responsible, productive and ethical citizens of the community. This will be attained within an educational environment that is characterised by high standards, a well-defined curriculum and exceptional staff (the best in the world) in partnership with parents and the wider community." As indicated in this vision and mission, the principal believed in focusing on a holistic approach to education and not only on academics, sports and culture.

Since leadership and schools have become so complex, the principal realised the importance and his responsibility to develop himself (Steyn 2007, 2010). The principal believed that the growth of staff and the school depended upon this growth. He explained:

The whole thing is self-development-I think that's the most important. If you are not growing, you are dying ... You must search, you must do research, you must listen, you must look, you must attend courses... You must force yourself ... Especially on your specific role and skills ... you need to accept responsibility for yourself and, as I said to you, if you don't grow yourself, the people under you don't grow.

The principal showed the necessity for schools to continue to grow to meet global and societal challenges. In the story he said:

I showed a photo of how schools looked 50 years ago and how they look today - and the only difference was the colour of the photo ... Is there something else in the schools? Do we approach the child differently? ... The world is growing, so education must also grow. Your methodology must grow, the way you approach the child ... So the [main] thing is to keep up,... I know that what works in place A will not necessarily work in place B, but you must find out what's important for you, in your environment.

He believed that the education system is "losing the essence of life", as he explained:

But we are pushing these children so much, culturally, academically and in sport, that we are losing the essence of life ... I would fight for the whole spiritual development of the child... we place too little value [on this] and people struggle and go downhill and become depressed and land up in hospitals and institutions ... I think we are missing something about the child ... they [children] have to start getting fit on the inside.
To him, the joy of all role players was essential: "One can't just go to school, day in and day out." Every staff member should come to school "with a song in his [or her] heart". He added: "I' $m$ increasingly beginning to realise that the people who really make a success of everything [are the ones] with heart - that's the thing." Such teachers would be able to "excite others", in particular their learners. He believed that he as principal played a major role in the happiness of people and that he was in a fortunate position to motivate and encourage people, particularly his staff. The principal often reminded his staff about Phil Collins's song " Another day for you and me in Paradise', because you are in paradise" (Steyn 2006: 12, 2007: 273). The effect of inculcating happiness in students is illustrated by the following comment:

What I've seen is that children were spontaneous and happy ... A mother once told me that she is so happy. Her child doesn't even say hello to her in the morning but, when the child sees me, she jumps out out of the car and runs over to say hello. She embraced me... It meant a lot to me.

Providing servant leadership implies turning the traditional pyramid of organisations upside down: it means sharing the power of leaders and making leadership collective and collaborative (Trompenaars and Voerman 2010: 30).

\section{Sharing Leadership: "The secret of any business ... is ownership"}

Laub's OLA model (1999: 25) regards leaders as servant leaders when they facilitate a shared vision, share power and release control, share their status and promote others. Servant leadership and empowerment are closely linked and servant leaders empower others "to find their own paths, and they, in turn, are inspired to help others find their best paths" (Patterson 2003: 6). The principal's story supported this view: "Everyone is actually a leader ... I believe that leaders are everywhere, so you must work on their leadership skills ... a person has to be shaped." He explained the essence of empowerment:

The secret of any business ... is ownership ... one of the most important things is for all role players to accept ownership ... and you must think of very fine methods to develop joint responsibility. Children should have the privilege to being able to have a say in the manage- 
ment of a school. Parents should have the privilege ... I think everyone has an astonishing say and value.

The principal's approach to decision making was collaborative and democratic. In his story, the principal confirmed the necessity of taking "the people with you". He clearly explained his stance in Steyn (2006: 7):

If you are not able to take the people with you, you are going to lose contact with your people. So you have to make sure that you do not move too far ahead of them ... I think one has to be able to make them excited ... so that they can begin to believe in themselves and do things for themselves.

Sharing leadership was important to him, but even more important was leaving the school with the likelihood that the school would become better after he had left. In this regard he said: "If you leave and the place collapses, then it's your fault." The "greatest gift" that he wanted to give to the school was a place that would became better after he left.

This view explains why it was important for the principal to empower people "beyond" himself so that they could run the school without him after he retired. He did not regard himself as the key player in the school, but wanted to create a community of leaders that could lead the school to more successful even without him.

\section{DISCUSSION AND REFLECTION}

The significance of the principal's leadership lies in the fact the principal remarkably revealed characteristics that are supported by Laub's servant leadership model (see Fig. 1). It was mainly the core values of the principal that influenced

\section{PRINCIPAL'S CORE VALUES AND PERSONAL TRAITS}

Valued people: "very people oriented"; extraordinarily blessed with a great love for people - especially for children
Displayed authenticity: "Compassion": stopping to listen; saying nothing; being there where things are happening; humility the crux of leadership; honouring and respecting others; passion for education

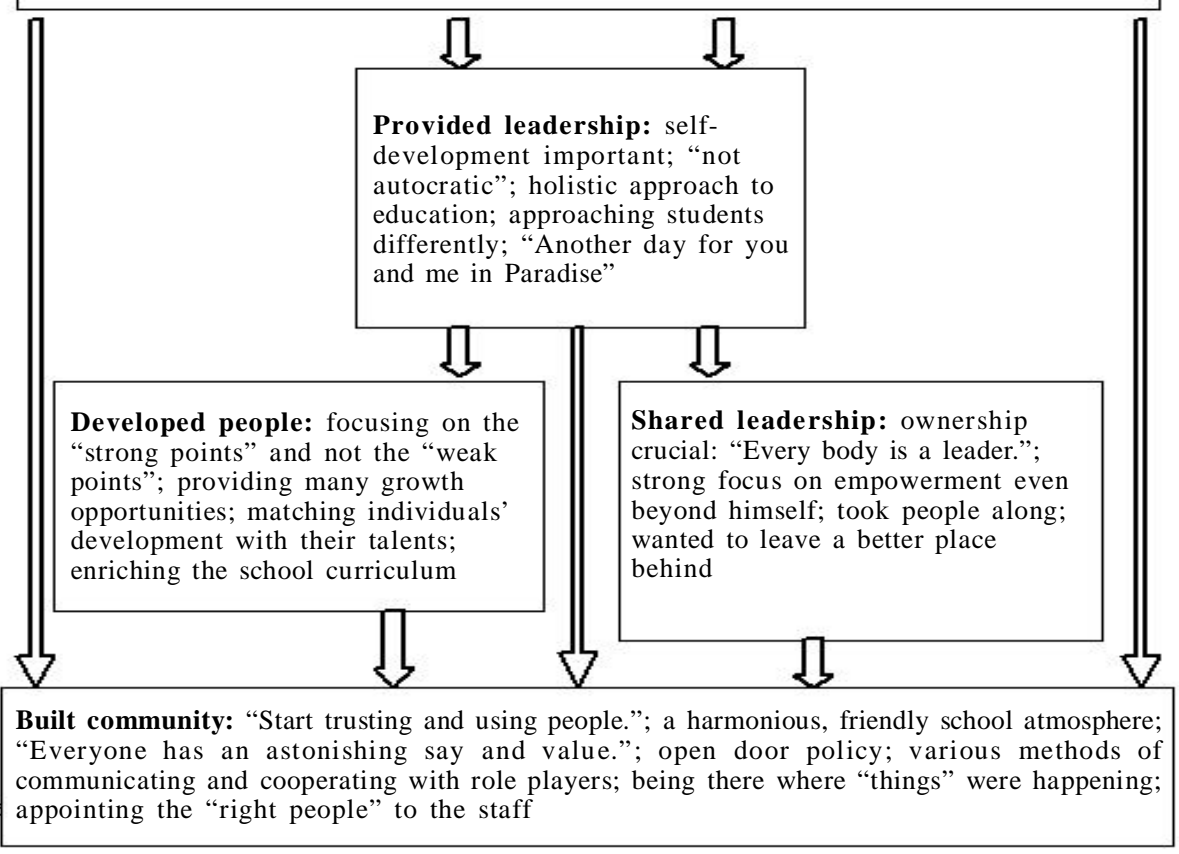

Fig. 1. The manifestation of the servant-leadership practice of the principal 
each of the other characteristics of the servant leadership model. Firstly, the findings show how the principal valued people through his passion and care for people. This characterised him as a servant leader. Servant leaders, as in the case of this principal, value people and place a high priority on care to ensure that other people's needs are best served (Cerit 2010: 304; Greenleaf 1998: 19; Jacobson et al. 2005: 613; Norris et al. 2002: 80; Saðnak 2010: 1145; Trompenaars and Voerman 2010: 27). Servant leadership is about "a school leader having a servant's heart' (Hagstrom 2004: 84), which is also described in the principal's narrative. Other values that the principal portrayed also agreed with those found in the Australian study on successful school leadership (Gurr et al. 2005: 545; Gurr et al. 2006: 381 ) indicating that every person is important, every student can succeed, every child has unrealised potential and the school should focus on what is in the best interests of all students. Moreover, as in the studies done by Norris et al. (2002: 77) and Printy (2010: 113) the principal showed that his caring about others moved beyond caring about self and he demonstrated a sincere interest in the development and welfare of others.

Secondly, displaying authenticity is a requirement for being a servant leader which was demonstrated uniquely by the principal's leadership practice. In this narrative other core values and personal traits of the principal influenced his servant leadership practice. They included his compassion, his availability to listen, his humility and respect of other people. Servant leaders have passion (Spears 2010: 27; Trompenaars and Voerman 2010:33) and the principal explicitly expressed his own passion for education as well as his longing that this passion would be present in his teachers' approach to teaching. Hagstrom (2004: 85 ) believes that "leadership is being a servant of people... and the new pioneer who finds the way to make their hearts sing". Another leadership quality that emerged from the narrative was the principal's humility and willingness to listen to the needs of others. Servant leaders are humble and are willing to listen (Spears 2010: 27; Patterson 2003:4). The principal had the ability to show the correct emotions at a given moment in the "context of controlled humility" (Trompenaars and Voerman 2010: 33). To be able to do this the principal listened carefully and was open to the needs of others as reflected by other studies on successful leadership (Jeffries 1998: 32; Jacobson et al. 2005: 613; Raihani 2008: 491).

Thirdly, the principal's values and personal traits influenced his particular leadership approach through which he envisioned the future, established the necessary initiatives and set supporting goals. A vision has the potential to generate excitement, passion and energy and to empower all role players: it is also necessary to obtain the school's objectives (Gurr et al. 2006: 381; Hoy and Smith 2007: 162; Pankake and Moller 2003: 7; Spears 2010: 27). In a previous study the principal stated that one of his "strong points" was to be a visionary leader (Steyn 2006: 6). This school's vision consisted of four parts: a focus on every student; safe, caring and positive relationships in the school environment; expectations which focused on values regarding the behaviours and actions of staff, students and parents and the scope of the vision which included lifelong learning and community social capital (cf Spears 2010: 29). The principal wanted the school to be the "best Afrikaans school", but he believed in focusing on a holistic approach to learning rather than exclusively on academics, sports and culture. In a developing society, the education system should also adapt, which explains why the principal required a vision to refocus on the child. This also supported the principal's view of the importance of continuous improvement to meet ever-changing societal challenges. The principal did this by establishing whole-staff consensus on school goals. The principal also directed role players' behaviour professionally towards the shared school goals by way of the necessary communication (Jacobson et al. 2005: 611; Gurr et al. 2006: 375; Spears 2010: 28) which included regular staff meetings, morning devotions in the staff room before school, weekly assemblies in the hall, weekly newsletters and parent evenings. He also constantly tried to remind staff about their working in paradise (the school) and he encouraged them to enjoy their calling as educators.

Fourthly, while the principal's leadership influenced his approach to developing people on the one hand, it also showed how he shared leadership in the school. As servant leader, he had a passion to assist staff and students to develop and grow (Trompenaars and Voerman 2010: 35; Kelly and Saunders 2010: 138), even beyond himself. For teacher development the 
principal provided ample growth opportunities so that teachers could learn necessary skills to emerge as leaders (Danielson (2007: 19). It was crucial for the principal to identify the potential of individuals and then match the potential of individuals to particular tasks (Nel et al. 2008: 369; Spears 2010: 29; Trompenaars and Voerman 2010: 31). The school annually budgeted for professional development which included outside and school-based programmes, providing proof of his commitment to developing his staff. The aim of these growth opportunities was to assist teachers to develop to their full potential while also becoming committed to contributing to the school's goals. He regarded his own professional development as crucial to encouraging the development of others and assisting the school's development.

Because the principal believed that many people can act as leaders, he provided opportunities for collective and collaborative shared leadership in the school (Hagstrom 2004: 98; Perumal 2009: 43; Spears 2010: 27). To this end, he accepted the responsibility as a school leader to facilitate the establishmment of a community of leaders within the school which, in essence, required an attitude of servanthood (Hagstrom 2004: 160). The principal created committees in which staff, students and parents were represented to assist in decision making (Jacobson et al. 2005: 616) which contradicted strategies that promote isolation and limit participation, and authoritarian approaches (Reyes and Wagstaff 2005: 109; Jacobson et al. 2005: 616). He believed that once role players had ownership of decision making, they were able to participate successfully in reshaping the school. Helping all school constituents to grow as leaders in the school and to encourage them to utilise their passion for the sake of the students and parents they serve, almost invariably creates an effective leadership community (Hagstrom 2004: 84).

Lastly, the characteristics of the principal's servant-leadership approach described above culminate in his creation of a particular community within the school. In line with this, Aelterman in Engels et al. (2008: 161) refers to the crucial role of principals in the well-being of staff, collegial relationships between staff members and staff's commitment to PD and school development. Other studies confirm the importance of harmonious relationships among staff since they have a crucial impact on students' performance
(Louis et al.2010: 325; Gurr et al. 2005: 546). This implies that principals should determine the strengths and weaknesses of the school community in order to find ways of promoting, encouraging and energising the individual talents of students, teachers and parents. By being "present" on the school grounds, which the principal advocated and demonstrated,made it was possible to create a bond and enhance effective collaboration between the principal and other role players in the school (McClain and Romaine 2007: 8). His type of leadership also promoted teamwork, collaboration, self-esteem and even self-actualisation among the constituents in the school (Jacobson et al. 2005 613; Katz and Earl 2010: 30; Louis et al. 2010: 323; Patterson 2003: 5; Printy 2010: 115; Reyes and Wagstaff 2005: 110).

\section{CONCLUSION}

In this study the researcher has attempted to provide some insight into the leadership practice of a principal and the way in which it reflects the characteristics of servant leadership. The study demonstrates that a narrative allows a storyteller to generate educational knowledge.

Considering the length of the principal's career as school leader, it is important to realise servant leadership takes time to develop and that it encompasses a way of living and leading through serving others. Moreover, a number of traits characterise principals as servant leaders: they enhance the valuing and growth of people, they collaborate in order to build communities, they practice authenticity and they provide and also share leadership in their schools. This study found that the principal's personal set of values formed the foundation of his leadership practice and directed him in his decisions and actions regarding the development of the people, the building of a school community, his preferred leadership style and the sharing of leadership in the school. These values also assisted a principal not only to focus on challenges within the school, but also to adopt appropriate strategies to cope with the increased complexity of the school environment. It is therefore reasonable to suggest that at least part of the principal's servant leadership success was a result of these personal and professional values and prudent and continuing exercising of his focus on people and their happiness. 
Despite the valuable findings, there is a limitation to the study. It involves the intricate relationship between the contextual factors in a particular school and execution of school leadership. This leads me to state that there is a need to develop leadership theories in order to can enhance our understanding of school contexts within which effective leadership, in particular servant leadership takes place.

\section{ACKNOWLEDGEMENTS}

This work is based upon research supported by the National Research Foundation in South Africa

\section{REFERENCES}

Atkinson P, Delamont S (Eds.) 2011. SAGE Qualitative Research Methods. London: Sage Publications, Inc.

Barker RA 2001. The nature of leadership. Human Relations, 54(4): 395-525.

Bell JL 2002. Narrative inquiry. More than just telling stories. TESOL Quarterly, Sum, 36 (2): 207-213.

Brumley C 2007. Louisiana's Successful Combination School Principals: A Narrative Inquiry of Professional Beliefs and Practices Through a ServantLeadership Lens (Abstract). DEd Dissertation. Stephen F. Austin State University, TX. From $<$ http://gateway.proquest.com/openur $1 \% 3$ furl_ver=Z39.88-2004\%26 res_dat=xri:pqdiss $\%$ 26 rft_val_fmt $=$ info:ofi/fmt:kev:mtx: dissertation\%26rft_dat=xri:pqdiss:3301658> $(\mathrm{Re}-$ trieved August 3, 2011).

Cerit Y 2010. The effects of servant leadership on teachers'organizational commitment in primary schools in Turkey. International Journal of Leadership in Education, 13(3): 301-317.

Clandinin D J (Ed.) 2007. Handbook of Narrative Inquiry. Mapping a Methodology. Thousand Oaks, CA: Sage Publications, Inc.

Cooper JE, Heck RH 1995. Using narrative in the study of school administration. International Journal of Qualitative Studies in Education, 8(2): 195210 .

Creswell JW 2007. Qualitative Inquiry and Research Design: Choosing among Five Approaches. $2^{\text {nd }}$ Edition. Thousand Oaks, CA: Sage Publications.

Daiute C, Lightfoot C 2004. Narrative Analysis: Studying the Development of Individuals in Society. Thousand Oaks, CA: Sage Publications, Inc.

Danielson C 2007. The many faces of leadership. Educational Leadership, Sept, 65(1): 14-19.

Denzin NK, Lincoln .S 2008. Collecting and Interpreting Qualitative Materials. Thousand Oaks, CA: Sage Publications.

Dobbs R, Walker R 2010. Transformational Leadership: A Blueprint for Real Organizational Change. Little Rock, AR: Parkhurst Brothers.
Drysdale L, Goode H, Gurr D 2009. An Australian model of successful school leadership. Journal of Educational Administration, 47(6): 697-708.

Engels N, Hotton G, Devos G, Bouckenooghe D, Aelterman A 2008. Principals in schools with a positive school culture. Educational Studies, July, 34(3): 159-174.

Fry LW, Kriger M 2009. Towards a theory of beingcentered leadership: Multiple levels of being as context for effective leadership. Human Relations, 62(11): 1667-1696.

Given LM 2008. The SAGE Encyclopedia of Qualitative Research Methods. Thousand Oaks, CA: SAGE Publications, Inc.

Greenleaf RK 1998. Servant-leadership. In: LC Spears (Ed.): Insights on Leadership: Service, Stewardship, Spirit, and Servant Leadership. New York: John Wiley and Sons, pp. 15-20.

Greer CJ 2009. Narrative inquiry and school leadership identities. International Journal of Leadership in Education: Theory and Practice, 12(3): 269-282.

Gurr D, Drysdale L, Mulford B 2005. Successful principalship: Australian case studies. Journal of Educational Administration, 43(6): 539-551.

Gurr D, Drysdale L, Mulford B 2006. Models of successful principal leadership. School Leadership and Management, 26(4): 371-395.

Hagstrom D 2004. From Outrageous to Inspired: How to Build a Community of Leaders in our Schools. San Francisco, CA: Johan-Wiley and Sons.

Hallinger P, Heck RH 1998. Exploring the principal's contribution to school effectiveness: 1980-1995. School Effectiveness and School Improvement, 9 (2): 157-191.

Hersey P, Blanchard KH, Johnson DE 2008. Management of Organizational Behavior: Leading Human Resources. 9 $^{\text {th }}$ Edition. Upper Saddle River, NJ: Pearson Prentice Hall.

Hollingsworth S, Dybdahl M 2007. Talking to learn: The critical role of conversation in narrative inquiry. In: DJ Clandinin (Ed.): Handbook of Narrative Inquiry: Mapping a Methodology. Thousand Oaks, CA: Sage Publications, Inc, pp. 146- 177.

Hoy WK, Smith PA 2007. Influence: A key to successful leadership. International Journal of Educational Management, 21(2): 158-167.

Huffman JB, Hipp KK 2003. Restructuring Schools as Professional Learning Communities. Lanham, MD: Scarecrow Education.

Jacobson S L, Johnson L, Ylimaki R, Giles C 2005. Successful leadership in challenging US schools: Enabling principles, enabling schools. Journal of Educational Administration, 43(6): 607-618.

Jeffries E 1998. Work is a calling. In: LC Spears (Ed.): Insights on Leadership: Service, Stewardship, Spirit, and Servant Leadership. New York, NY: Johan Wiley and Sons, Inc, pp. 29-37.

Johnson G C 2009. Narrative inquiry and school leadership identities. International Journal of Leadership in Education: Theory and Practice, 12(3): 269-282.

Karadað E 2009. Spiritual leadership and organisational culture: A study of structural equation modelling. Educational Sciences: Theory and Practice, 9(3): $1391-1405$. 
Katz S, Karl L 2010. Learning about networked communities. School Effectiveness and School Improvement, 21(1): 27-51.

Kelly A, Saunders N 2010. New heads on the block. Three case studies of transition to primary headship. School Leadership and Management, 30(2): 127-142.

Krüger ML, Witziers B, Sleegers P 2007. The impact of school leadership on school level factors: Validation of a causal model. School Effectiveness and School Improvement, 18(1): 1-20.

Ladkin D 2010. Rethinking Leadership: A New Look at Old Leadership Questions. Cheltenham, UK: Edward Elgar.

Laub JA 1999. Assessing the Servant Organization: Development of the Organizational Leadership Assessment (OLA) Instrument. A Brief Synopsis of a Dissertation. The College of Education, Florida Atlantic University, Florida.

Laub JH 2004. The life course of criminology in the United States: The American Society of Criminology 2003 Presidential Address. Criminology, 42 (1): $1-26$.

Leithwood K, Day C 2007. Starting with what we know. In: D Day, K Leithwood (Eds.): Successful Principal Leadership in Times of Change: An International Perspective. Dordrecht, Netherlands: Springer, pp.1-16.

Lou is KS, Dretzke B, Walhstrom K 2010. How does leadership affect student achievement: Results from a national US survey. School Effectiveness and School Improvement, 21(3): 315-336.

Mphahlele R E 2009. A Decade of Educational Change. Grounded Narratives of School Principals. Ph.D. Thesis, Unpublished. University of Pretoria, Pretoria.

Macneil A J, Prater D 1, Busch S 2009. The effects of school culture and climate on student achievement. International Journal of Leadership in Education 12(1): 73-84.

McClain G, Romaine DS 2007. The Everything Managing People Book. $2^{\text {nd }}$ Edition. Avon, MA: Adams Media.

Mogadime D, Mentz K, Armstrong DE, Holtam B 2010. Constructing the self as leader: Case studies of women who are change agents in South Africa. Urban Education, 45(6): 797-821.

Møller J, Eggen AB 2005. Team leadership in upper secondary education. School Leadership and Management, 25(4): 331-347

Muijs D, Ainscow M, Dyson A, Raffo C, Goldrick S, Kerr K, Lennie C, Miles S 2010. Leading under pressure: Leadership for social inclusion. School Leadership and Management, 30(2): 143-157.

Nel PS, Werner A, Haasbroek G D, Poisat P, Sono T, Schultz HB 2008. Human Resources Management. $7^{\text {th }}$ Edition. Cape Town: Oxford University Press, Southern Africa.

Norris C J, Barnett BG, Basom MR, Yerkes DM 2002. Developing School Leaders. A Working Model: The Learning Community in Action. New York: Teachers' College, Columbia University.

Oplatka I 2004. The arrival of a new principal and teachers' self-renewal: Reflections from life stories and mid-career teachers. Planning and Changing, 35(1/2): 43-68.
Pankake AM, Moller G 2003. Overview of professional learning communities. In: JB Huffman, KK Hipp (Eds.): Restructuring Schools as Professional Learning Communities. Lanham,MD: Scarecrow Education.

Patterson K 2003. Servant Leadership: A Theoretical Model. Proceedings of the Servant Leadership Roundtable. From<http://images.puizaza02. multiply.multiplycontent.com/attachment/0/ TX5ZnQooCs8AAAd0H-c1/patterson_servant_ leadership. pdf?key= puizaza02:journal: 26 and nmid $=424750328>$ (Retrieved July 14, 2011).

Perumal J 2009. Reading and creating critically leaderful schools that make a difference: The post-apartheid South African case. International Journal of Leadership in Education, 12(1): 35-49.

Printy S 2010. Principals' influence on instructional quality: Insights from US schools. School Leadership and Management, 30(2): 111-126.

Reyes P, Wagstaff L 2005. How does leadership promote successful teaching and learning for diverse students? In: WA Firestone, C Riehl C (Eds.): $A$ New Agenda for Research in Educational Leadership. New York, NY: Teachers College, Columbia University, pp. 101-118.

Riesmann CK 2011. Doing narrative analysis. In: P Atkinson, S Delamont (Eds.): SAGE Qualitative Research Methods. Volume 111. London: Sage Publications, Inc, pp.201-211.

Robbins SP, Decenzo DA 2004. Fundamentals of Management. Essential Concepts and Applications. $4^{\text {th }}$ Edition. Upper Saddle River, NJ: Pearson, Prentice Hall.

Ross DB 2006. Perceptions of the Evidence of a Servant Leadership Culture Among Educators in the P-12 School System in the North American Division of the Seventh-Day Adventists. Doctoral Degree (With Dissertation), Unpublished. Andrews University, School of Education, Berrien Springs, MI.

Saðnak M 2010. The relationship between transformational school leadership and ethical climate. Educational Sciences: Theory and Practice, Spring, 10(2): 1135-1152.

Schall E, Ospina S, Godsoe B, Dodge J 2004. Appreciative Narratives as Leadership Research: Matching Method to lens. From<http://wagner.nyu.edu/leadership/publications/files/matching method tolens. pdf $>$ (Retrieved April 6, 2011).

Spears LC 2004. Practicing servant-leadership. Leader to Leader, 34: 7-11.

Spears LC 2010. Character and servant leadership: Ten characteristics of effective, caring leaders. The Journal of Virtues and Leadership, 1(1): 25-30.

Spillane JP 2005. Distributed leadership. The Educational Forum, 69: 143-150.

Steyn GM 1994. Die sigbaarheid van die skoolhoof as bestuursbenadering: " $n$ Gevallestudie ('The visibility of the principal as leadership approach: A case study'). Onderwysbulletin, 2(2), XXXV111:16-31.

Steyn T 2006. Sustaining an inviting culture in a South African school: A case study. Journal of Educational Studies, 5(1): 1-15.

Steyn G M 2007. Adhering to the assumptions of invitational education: A case study. South African Journal of Education, 27(2): 265-281. 
Steyn GM 2009. Using reflexive photography to study a principal's perceptions of the impact of professional development on a school: A case study. Koers, 74(3): 1-29.

Steyn GM 2010. 'n Skoolhoof se perspektief op professionele ontwikkeling: 'n Enkele gevallestudie (A school principal's persective on professional development: a single case study'). Tydskrif vir Geesteswetenskappe, 50(2): 244-261.

Steyn GM 2012. Reflections on school leadership focussing on moral and transformational dimensions of a principal's leadership practice. Journal for Christian Scholarship (In Press).

Tidball D 2012. Leaders as servants: A resolution of the tension. ERT, 36(1): 31-47

Trompenaars F, Voerman E 2010. Servant-leadership Across Cultures. New York: McGraw-Hill.

Van Tassell M 2006. Called to Serve: Servant-Leadership Perceptions at a Fransciscan-Sponsored University Correlated with Job Satisfaction. Doctoral Dissertation, Unpublished. Cappella University, Minneapolis, MN. 